\title{
Macrobenthic turnover in the subtidal Wadden Sea: the Norderaue revisited after 60 years
}

\author{
K. Reise \& A. Schubert \\ Biologische Anstalt Helgoland (Litoralstation); D-2282 List, FRG \\ and \\ II. Zoologisches Institut und Museum der Universität; Berliner Straße 28, \\ D-3400 Göttingen, FRG
}

\begin{abstract}
The benthic macrofauna of a tidal inlet in the northern Wadden Sea was sampled with grab and dredge in 1924-1926 (Hagmeier \& Kändler, 1927), and again in 1985 and 1986. The comparison of surveys from consecutive years, as well as observations from an adjacent area, are employed to separate spurious from real long-term changes. Several epibenthic species of the 1920s became rare or absent in the 1980s. Oyster beds and reefs of the colonial polychaete Sabellaria spinulosa have disappeared completely. On the other hand, mussel beds have extended their range, and the abundance of mobile infauna has increased. The total number of species has remained approximately the same. Compared to surveys from consecutive years, the 60 -year interval has doubled the species turnover rate, and has decreased the similarity in relative abundances by one third. The observed losses are best explained by the impact of dredging and trawling on the benthic fauna, while gains seem to indicate coastal eutrophication.
\end{abstract}

\section{INTRODUCTION}

As part of a benthic effects-monitoring programm in the German North Sea, involving continuous time series as well as comparisons of discrete intervals, we investigated the subtidal macrofauna of the northern Wadden Sea. The first quantitative descriptions of the macrobenthos in the Wadden Sea were provided in the 1920s by Hagmeier \& Kändler (1927; hereafter: H \& K). Sampling was done mainly in two areas. One area was the Lister Ley near the island of Sylt, the other the Norderaue between the islands of Föhr and Langeness.

In an attempt to document long-term changes in the benthic fauna, we reinvestigated the Sylt area in 1980 (Riesen \& Reise, 1982). Natural oyster beds had all gone, presumably because of overexploitation. Reefs built by the polychaete Sabellaria spinulosa stood in the way of shrimp trawling and were destroyed. A subtidal Zostera marina bed was wiped out in 1934 by an epidemic disease, never to return. These losses affected various associated species. However, total species richness remained about the same because mussel beds spread in the entire region, and many polychaete species took advantage of this expansion.

Here we report on the faunal changes observed in the second area, which was investigated by $\mathrm{H} \& \mathrm{~K}$. In the survey of the Norderaue, they visited some sites in 1925 and 
other sites in 1926. By contrast, we visited all sites in 1985 and the same sites in 1986. For direct comparison, we selected from this larger set of samples, the sites and years as chosen in the 1920s. The three separate surveys were used to differentiate between apparent and real long-term changes. The species turnover observed between 1985 and 1986 is regarded as sampling error plus year-to-year variability. Subtracting this rate from the one obtained for the 60-year interval, may yield an estimate of the real longterm species turnover.

\section{AREA AND METHODS}

Object of investigation is the macrobenthos in the subtidal region of the Norderaue, between the island of Föhr and Hallig Langeness (Fig. 1). The Norderaue is a tidal inlet off the west coast of Schleswig-Holstein, Federal Republic of Germany. The channel bed has a depth of up to $22 \mathrm{~m}$ below low tide level. Tidal range is $2.8 \mathrm{~m}$. Maximum ebb and flow velocities are 1.35 and $1.25 \mathrm{~m} \mathrm{~s}^{-1}$, respectively. Salinity varies between 29 and $32 \%$, and water temperature between $0^{\circ}$ and $20^{\circ} \mathrm{C}$, with a summer average of $15^{\circ} \mathrm{C}$. Sediments are mostly sand or muddy sand, occasionally with some gravel.

The area was described and sampled by $\mathrm{H} \& \mathrm{~K}$. They provided data from dredging oyster beds (see W, S and N in Fig. 1) in autumn 1924, and from grab samples (Petersen grab of $75 \mathrm{~kg}$ and $0.1 \mathrm{~m}^{2}$ ), sieved with a 1-mm mesh. Four samples were taken from bed

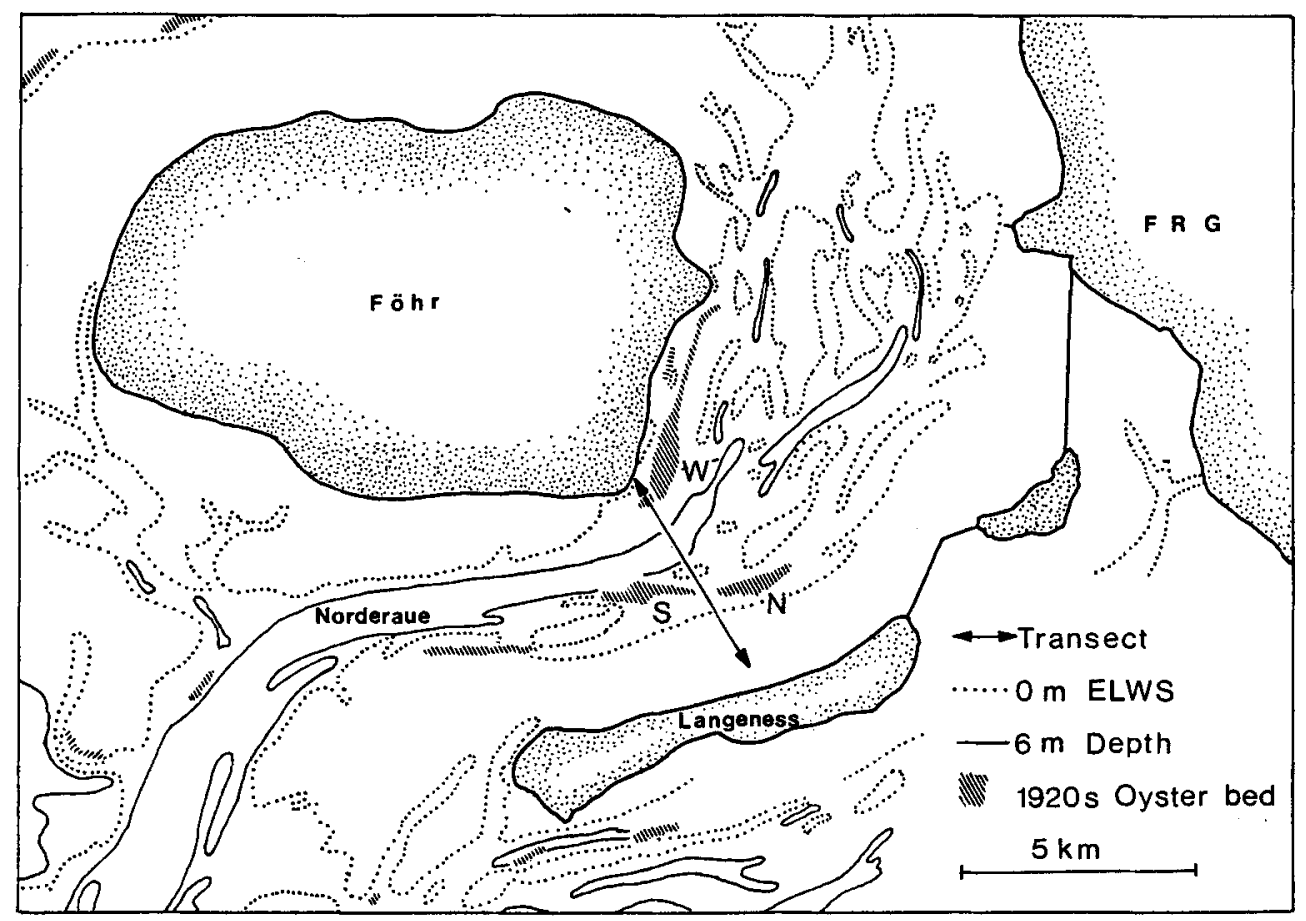

Fig. 1. Study area in the northern Wadden Sea between the island of Föhr and Hallig Langeness. Former oyster beds (dark shading) revisited: $W=$ Wyker Bank, $S=$ Schmaltiefskant, $N=N$ Neßwatt, ELWS = extreme low water spring tide line 
W, and two from S/N, some time between 1924 and 1926. Along a transect between Föhr (windmill in Wyk) and Langeness (chapel), 21 samples were obtained from 15 sites. A depth profile is given with sampling sites, type of sediment, and conspicuous epifauna schematically indicated. This transect was sampled in Juli 1925 (10 sites) and June 1926 (5 sites).

We revisited all these sampling sites, both in August 1985 and in June 1986. The dredge used was of the same type (blade length $1 \mathrm{~m}$, mesh size $60 \mathrm{~mm}$, dredging time $10 \mathrm{~min})$, while the grab was a van Veen sampler $\left(55 \mathrm{~kg}, 0.1 \mathrm{~m}^{2}\right)$. In accordance with $\mathrm{H}$ \& $\mathrm{K}$, grab samples of $<51$ were discarded. Sieving was done on board, and living animals were picked up from white dishes. Sixteen of the total of 27 grab samples obtained by $\mathrm{H}$ $\& \mathrm{~K}$ are from 1925, 5 from 1926, and for 6 no exact date was given. We took 27 samples in 1985 , and the same number in 1986. To compare the period 1985-86 with 1925-26, we allotted our samples in the same way as $\mathrm{H} \& \mathrm{~K}$ did. From the two sites where exact dates were missing, we arbitrarily apportioned 2 samples (site $\mathrm{S} / \mathrm{N}$ ) to 1985 and 4 samples (site W) to 1986.

Species turnover rate between separate surveys is expressed as $T=(A+B) /\left(S_{A}+S_{B}\right)$. $A$ is the number of species which are present in the first survey but are absent in the second one. $B$ is the respective number for those absent in the first but present in the second survey. $S_{A}$ is the total number of species found in the first and $S_{B}$ in the second survey (see Schoener, 1983). This index is equivalent to $1-Q_{\mathbf{s}}$ where $Q_{s}$ is Sørensen's index of similarity, based on presence-absence data. Affinities between surveys are expressed with Renkonen's index $R_{e}=\Sigma p_{s}$. Relative abundances (fractions of 1) of species within each survey are calculated, then the lower fraction of each species $\left(p_{s}\right)$ is chosen, and these are summed up over the entire set of species.

\section{RESULTS}

\section{Habitat structure}

We recorded the depth profile with an echo depth sounder, and revisited sites according to relative position, depth and type of sediment. The distribution of sediments was about the same as in the 1920s, except where mussels showed up in 1985-86 but not in 1925-26. In these instances, the sediment became more muddy. As more mussel beds were present in 1985 than in 1986, less sites contained mud in the second year.

The depth profiles of 1925-26 and 1985-86 are similar. The opposite is true for the conspicuous components of the epifauna (Fig. 2). The three-zoned pattern showing mussels above, oysters in between, and Sabellaria reefs below in the 1920 s, is substituted by an all-mussel pattern in the 1980s. No oysters were found in 1985-86, although some shells were still present. Sabellaria reefs had all gone. Only a few clumps of agglutinated, empty tubes were found. Mussel beds and mussel shells were very common in 1985 . The latter prevailed in 1986. In the 1920 s, mussel beds were mainly restricted to the shallows. 


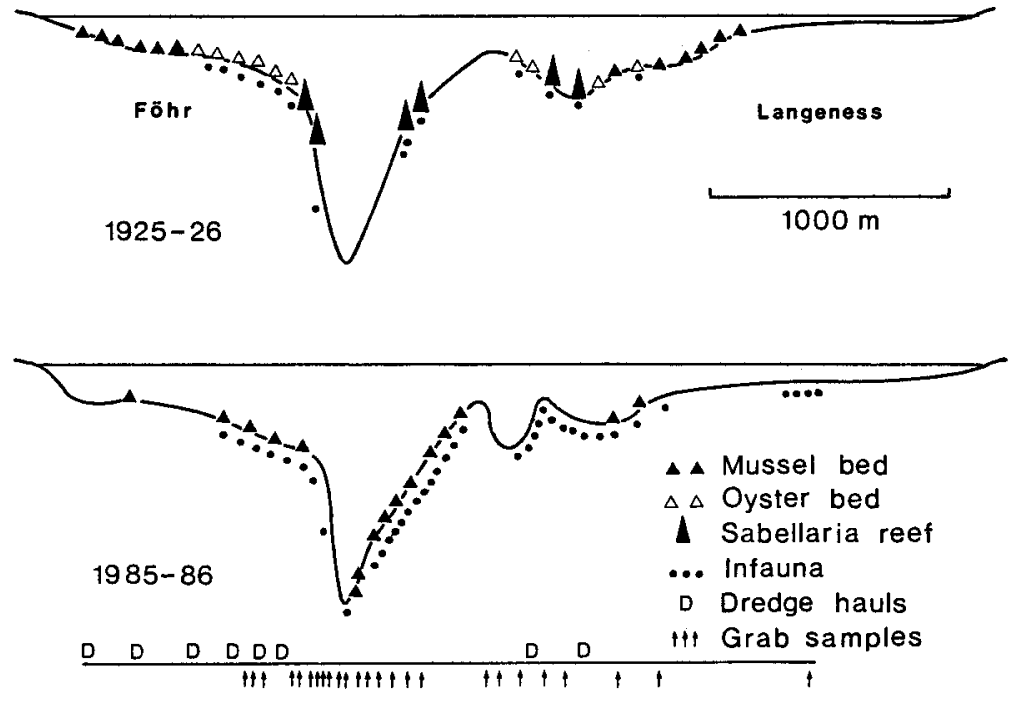

Fig. 2. Schematic presentation of macrobenthic distribution along a depth profile across the Norderaue (see transect in Fig. 1) in the 1920s and 1980s. Below, positions of sampling sites are indicated

\section{Dredge hauls}

Four dredge hauls taken from oyster beds in 1924 are compared to 4 hauls in 1985 and 4 in 1986 from the respective sites (Table 1). Expressed in terms of presence-absence of taxa per haul, dredging was only half as successful in the 1980s compared to 1924 (see 'sum of constancy values' in Table 1). Constancy values declined in 13 taxa, remained about equal in 10, and increased only in 2 .

The turnover rates of taxa are 0.35 and 0.41 when dredgings of 1924 are compared with 1985 and 1986. For the 2 consecutive years, the turnover rate is only 0.19 . This may be regarded as a measure of sampling error plus the normal year-to-year variability (see 'pseudoturnover' in Nilsson \& Nilsson, 1983). Subtracting the latter from the former, gives an estimate of 16 to $22 \%$ for the real long-term turnover rate.

\section{Grab samples}

All grab samples from 1925-26 and from 1985-86 combined have similar abundances for the total fauna (Table 2). However, there are conspicuous differences when epifaunal and infaunal components are considered separately. Epifauna was more abundant in the 1920s, particularly when mussels are excluded from the comparison. The high values in the 1920 s were caused primarily by Sabellaria spinulosa. Infauna was less abundant in the 1920 s than in the 1980s. This difference is due to various taxa, not only to the group of small annelid worms. Quantities of the latter may easily result from small differences in the sieving procedure. 
Table 1. Constancy (expressed in ranks 0 to 4 ) of benthic invertebrates dredged from 4 sites in the Norderaue, in 1924 ( $\mathrm{H}$ \& K: p. 44), in 1985 and 1986. A = Anthozoa, B = Bivalvia, $\mathrm{Br}=$ Bryozoa, $\mathrm{D}=$ Decapoda, $\mathrm{E}=$ Echinodermata, $\mathrm{G}=$ Gastropoda and Polyplacophora, $\mathrm{H}=$ Hydrozoa, $\mathrm{P}=$ Polychaeta, Po $=$ Porifera

\begin{tabular}{|lccc|}
\hline Year of survey & 1924 & 1985 & 1986 \\
\hline Decrease in constancy & & & \\
B Ostrea edulis L. & 4 & 0 & 0 \\
P Sabellaria spinulosa (clumps) & 4 & 0 & 0 \\
P Nereis pelagica L. & 4 & 0 & 0 \\
H Sertularia cupressina L. & 3 & 0 & 0 \\
A Urticina felina (L.) & 3 & 0 & 0 \\
D Liocarcinus holsatus (Fabr.) & 3 & 0 & 0 \\
P Pomatoceros triqueter (L.) & 2 & 0 & 0 \\
H Eudendrium rameum Pallas & 2 & 0 & 0 \\
A Sagartiogeton undatus (Müller) & 2 & 0 & 0 \\
Po Halichondria panicea (clumps) & 4 & 1 & 1 \\
D Hyas araneus (L.) & 4 & 1 & 1 \\
E Psammechinus miliaris (Gmelin) & 4 & 0 & 1 \\
P Polynoidae & 4 & 2 & 0 \\
Similar constancy & & & \\
G Buccium undatum L. & & & \\
E Asterias rubens L. & 4 & 3 & 3 \\
D Pagurus bernhardus L. & 4 & 4 & 4 \\
Br Alcyonidium gelatinosum (L.) & 4 & 4 & 4 \\
A Metridium senile (L.) & 3 & 2 & 4 \\
D Carcinus maenas (L.) & 3 & 3 & 3 \\
G Lepidochitona cinerea (L). & 3 & 4 & 4 \\
H Tubularia indivisa L. & 1 & 1 & 2 \\
G Crepidula fornicata (L.) & 2 & 0 \\
P Lanice conchilega (Pallas) & 0 & 1 & 1 \\
Increase in constancy & 0 & 1 & 0 \\
G Littorina littorea (L.) & & & \\
B Mytilus edulis L. & 0 & & 3 \\
Sum of constancy values & 2 & 1 & \\
\hline
\end{tabular}

Table 2. Abundance (individuals below $2.7 \mathrm{~m}^{2}$ ) of epifaunal and infaunal macrozoobenthos (barnacles and colonial forms excluded) in the Norderaue, 1920s and 1980s. The values given for $1985 / 86$ are not calculated averages, but are from selected samples of the two years according to the sampling design adopted by $\mathrm{H} \& \mathrm{~K}$ in 1925 and 1926

\begin{tabular}{|lrrrr|}
\hline Year of survey & $1925 / 26$ & $1985 / 86$ & 1985 & 1986 \\
\hline Total & 1859 & 2067 & 3214 & 1735 \\
Epifauna & 1302 & 885 & 1918 & 554 \\
Epifauna without mussels & 1007 & 159 & 309 & 118 \\
Infauna & 557 & 1182 & 1296 & 1181 \\
Infauna without small worms & 535 & 961 & 1023 & 1061 \\
\hline
\end{tabular}


Table 3. Numerical characteristics of major macrozoobenthic taxa from 17 sites $\left(2.7 \mathrm{~m}^{2}\right)$ in the Norderaue area, sampled in 1925/26, in 1985 and 1986. Constancy refers to the number of sites $(0$ to 17). Species identification of annelids is incomplete (cf. $\mathrm{H} \& \mathrm{~K}$ ). Consult also legend of Table 2

\begin{tabular}{|c|c|c|c|c|c|}
\hline \multicolumn{2}{|c|}{ Year of survey } & \multirow[t]{2}{*}{$1925 / 26$} & \multirow[t]{2}{*}{$1985 / 86$} & \multirow[t]{2}{*}{1985} & \multirow[t]{2}{*}{1986} \\
\hline & Mollusca & & & & \\
\hline a & Individuals $2.7 \mathrm{~m}^{-2}$ & 367 & 739 & 1634 & 467 \\
\hline b & Sum of constancy values & 27 & 15 & 20 & 12 \\
\hline $\mathrm{c}$ & Diversity $b / a$ & .07 & .02 & .01 & .03 \\
\hline \multirow[t]{2}{*}{ d } & Number of taxa & 9 & 8 & 9 & 6 \\
\hline & Crustacea & & & & \\
\hline $\mathbf{a}$ & Individuals $2.7 \mathrm{~m}^{-2}$ & 221 & 393 & 385 & 508 \\
\hline b & Sum of constancy values & 50 & 51 & 51 & 49 \\
\hline c & Diversity b/a & .23 & .13 & 13 & .10 \\
\hline \multirow[t]{2}{*}{ d } & Number of taxa & 14 & 14 & 14 & 11 \\
\hline & Annelida & & & & \\
\hline a & Individuals $2.7 \mathrm{~m}^{-2}$ & 1232 & 877 & 1036 & 683 \\
\hline b & Sum of constancy values & 60 & 56 & 66 & 54 \\
\hline c & Diversity $b / a$ & .05 & .06 . & .06 & .08 \\
\hline d & Number of taxa & 8 & 8 & 8 & 8 \\
\hline
\end{tabular}

With regard to the three major taxa, molluscs, crustaceans and annelids, there are no conspicuous differences in abundance or in the number of taxa between the years in question (Table 3). Diversity is expressed as the sum of individuals divided by the sum of constancy values in order to combine aspects of dominance, species richness and spatial evenness in a single parameter. This index attains highest values for the period 1925-26 in molluscs and crustaceans. These taxa were analysed to the species level by $\mathrm{H} \& \mathrm{~K}$. In annelids, only a few species were listed separately.

When the abundance and constancy of species in the 1920s and 1980s are compared, there are rarely similarities (Table 4). A notable exception is the polychaete Scoloplos armiger. Common in 1925-26 but rare or absent in 1985-86 are the sea anemone Sagartiogeton viduata, the tellinid clam Abra alba, the reef-building polychaete Sabellaria spinulosa, and the amphipods Cheirocratus sundevalli and Phoxocephalus holbölli. Common in 1985-86 but rare or absent 60 years earlier are the mussel Mytilus edulis, phyllodocid polychaetes (mainly Anaitides maculata and Eulalia viridis), Nereis virens, smaller polychaetes, and the amphipod Bathyporeia sarsi. The latter was probably included under $B$. pilosa in the 1920s (see legend of Table 5).

These changes result in a high turnover rate of the taxa when the two periods are compared (Table 5). An estimate for the real long-term turnover rate may be obtained by subtracting the 1985-86 rate from the 1925/26-1985/86 rate. This yields a turnover of $16 \%$ of all taxa. Affinity between surveys is expressed with Renkonen's index which measures similarity mainly in terms of the dominant species. Compared to the two consecutive years, the 60-year interval causes a reduction of similarity by $33 \%$ (cf. 0.6 with 0.4 in Table 5).

The data provided in Tables 1 and 4 may be combined to calculate the turnover rate 
Table 4. Macrofauna (>1 mm) obtained from 17 sites in the Norderaue in 1925-26 (H \& K: pp. 28, 37, $41)$ and in 1985-86. Abundance refers to $2.7 \mathrm{~m}^{2}$ and constancy to the number of sites $(0 \text { to } 17)_{i}+$ present but not counted

\begin{tabular}{|c|c|c|c|c|}
\hline \multirow[t]{2}{*}{ Year of survey } & $1925-26$ & $1985-86$ & $1925-26$ & $1985-86$ \\
\hline & \multicolumn{2}{|c|}{ Abundance } & \multicolumn{2}{|c|}{ Constancy } \\
\hline \multicolumn{5}{|l|}{ Coelenterata } \\
\hline Sagartiogeton undatus (Müller) & 18 & 1 & 8 & 1 \\
\hline Sagartia troglodytes (Price) & 0 & 6 & 0 & 4 \\
\hline Metridium senile (L.) & 18 & 36 & 2 & 6 \\
\hline Hydroid colonies & + & + & 5 & 5 \\
\hline Alcyonidium sp. & 0 & + & 0 & 5 \\
\hline Nemertini & 0 & 7 & 0 & 3 \\
\hline \multicolumn{5}{|l|}{ Mollusca } \\
\hline Abra alba (S. Wood) & 31 & 0 & 9 & 0 \\
\hline Venerupis pullastra (Montagu) & 4 & 0 & 3 & 0 \\
\hline Macoma balthica (L.) & 4 & 1 & 4 & 1 \\
\hline Tellina fabula Gmelin & 1 & 0 & 1 & 0 \\
\hline Mya sp. (juv.) & 1 & 1 & 1 & 1 \\
\hline Mytilus edulis $\mathrm{L}$. & 295 & 726 & 2 & 6 \\
\hline Petricola pholadiformis Lamarck & 14 & 3 & 2 & 2 \\
\hline Buccinum undatum L. & 10 & 2 & 3 & 2 \\
\hline Ensis directus (Conrad) & 0 & 3 & 0 & 1 \\
\hline Littorina littorea (L.) & 0 & 2 & 0 & 1 \\
\hline Lepidochitona cinerea (L.) & 7 & 1 & 2 & 1 \\
\hline \multicolumn{5}{|l|}{ Annelida } \\
\hline Sabellaria spinulosa Leuckart & 853 & 0 & 9 & 0 \\
\hline Polynoidae (5 spp.) & 77 & 21 & 11 & 3 \\
\hline Nereis pelagica $\mathrm{L}$. & 1 & 0 & 1 & $\mathbf{0}$ \\
\hline Nereis virens Sars & 1 & 114 & 1 & 7 \\
\hline Nephtys (3 spp.) & 17 & 14 & 11 & 6 \\
\hline Ophelia limacina (Rathke) & 0 & 5 & 0 & 2 \\
\hline Scoloplos armiger (Müller) & 248 & 285 & 12 & 9 \\
\hline Phyllodocidae (3 spp.) & 13 & 171 & 7 & 10 \\
\hline Lanice conchilega (Pallas) & 0 & 46 & 0 & 5 \\
\hline Small Annelida (13 spp.) & 22 & 221 & 8 & 14 \\
\hline \multicolumn{5}{|l|}{ Crustacea } \\
\hline Balanus crenatus Bruguière & + & + & 8 & 7 \\
\hline Cheirocratus sundevalli (Rath.) & 78 & 0 & 6 & 0 \\
\hline Phoxocephalus holbölli (Kröyer) & 30 & 2 & 5 & 1 \\
\hline Paramphitoe bicuspis (Kröyer) & 3 & 0 & 1 & 0 \\
\hline Gammarus locusta (L.) & 2 & 0 & 2 & 0 \\
\hline Gammarus salinus Spooner & 0 & 46 & $\mathbf{0}$ & 4 \\
\hline Bathyporeia pilosa Lindström & 1 & 0 & 1 & 0 \\
\hline Bathyporeia pelagica (Bate) & 77 & 123 & 3 & 7 \\
\hline Bathyporeia sarsi Watkin & 0 & 104 & 0 & 10 \\
\hline Podoceropsis nitida (Stimpson) & 1 & 0 & 1 & 0 \\
\hline Corophium crassicome Bruzelius & 2 & 0 & 2 & 0 \\
\hline Corophium volutator (Pallas) & 0 & 22 & 0 & 3 \\
\hline Pontocrates arenarius (Bate) & $\mathbf{0}$ & 2 & 0 & 2 \\
\hline
\end{tabular}


Table 4 (Contd)

\begin{tabular}{|lcccc|}
\hline Year of survey & $\begin{array}{c}1925-26 \\
\text { Abundance }\end{array}$ & $\begin{array}{c}1925-26 \\
\text { Constancy }\end{array}$ \\
\hline Crustace a (contd) & & & & \\
Bodotria scorpioides (Montagu) & 5 & 3 & 4 & 2 \\
Gastrosaccus spinifer Goes & 2 & 3 & 2 & 2 \\
Crangon crangon (L.) & 10 & 13 & 6 & 2 \\
Liocarcinus holsatus (Fabr.) & 0 & 2 & 0 & 2 \\
Carcinus maenas (L.) & 4 & 54 & 4 & 5 \\
Hyas araneus (L.) & 0 & 15 & 0 & 2 \\
Pagurus bernhardus L. & 6 & 4 & 5 & 2 \\
Pycnogonum litorale Ström. & 2 & 0 & 1 & 0 \\
Psammechinus miliaris (Gmelin) & 2 & 0 & 2 & 0 \\
Asterias rubens L. & 0 & 8 & 0 & 3 \\
\hline
\end{tabular}

Table 5. Turnover rate of taxa based on presence-absence, and similarity based on relative abundances, between macrozoobenthic surveys of the Norderaue in the 1920s and 1980s. Calculated from Table 4. The species Bathyporeia sarsi Watkin, 1938 and Gammarus salinus (Spooner, 1947) had not yet been erected in the 1920s. For calculations, the former is assembled to B. pilosa and the latter to G. locusta

\begin{tabular}{|lcccc|}
\hline Surveys compared & $\begin{array}{c}1925 / 26- \\
1985 / 86\end{array}$ & $1985-1986$ & $\begin{array}{c}1925 / 26- \\
1985\end{array}$ & $\begin{array}{c}1925 / 26- \\
1986\end{array}$ \\
\hline Turnover rate & .32 & .16 & .33 & .35 \\
Renkonen's similarity & .40 & .60 & .32 & .41 \\
\hline
\end{tabular}

for the entire spectrum of species encountered in the 1920s and 1980s. The turnover between 1985 and 1986 is 0.13 . The one for the 60 -year interval is 0.26 . By subtraction, a real long-term turnover of $13 \%$ of the taxa is obtained.

\section{DISCUSSION}

Two major assemblages of the 1920s, oyster beds and Sabellaria reefs, are gone from the Norderaue area. Oyster beds are now either occupied by mussel beds or by an assemblage rich in polychaetes (Fig. 3). The sites of former Sabellaria reefs may also be occupied by mussels or by an assemblage of sand-dwelling amphipods (Bathyporeia spp.).

\section{Consistency of evidence}

Caution is advised in the comparison of benthic surveys, when equipment and procedures are not exactly alike. However, differences in methods are hard to avoid when studies are separated by 60 years. Furthermore, the design and presentation of the survey carried out by $\mathrm{H} \& \mathrm{~K}$ do not allow a comparison based on statistical tests. Erroneous interpretations may be avoided: (1) by disregarding all minor deviations, (2) by 


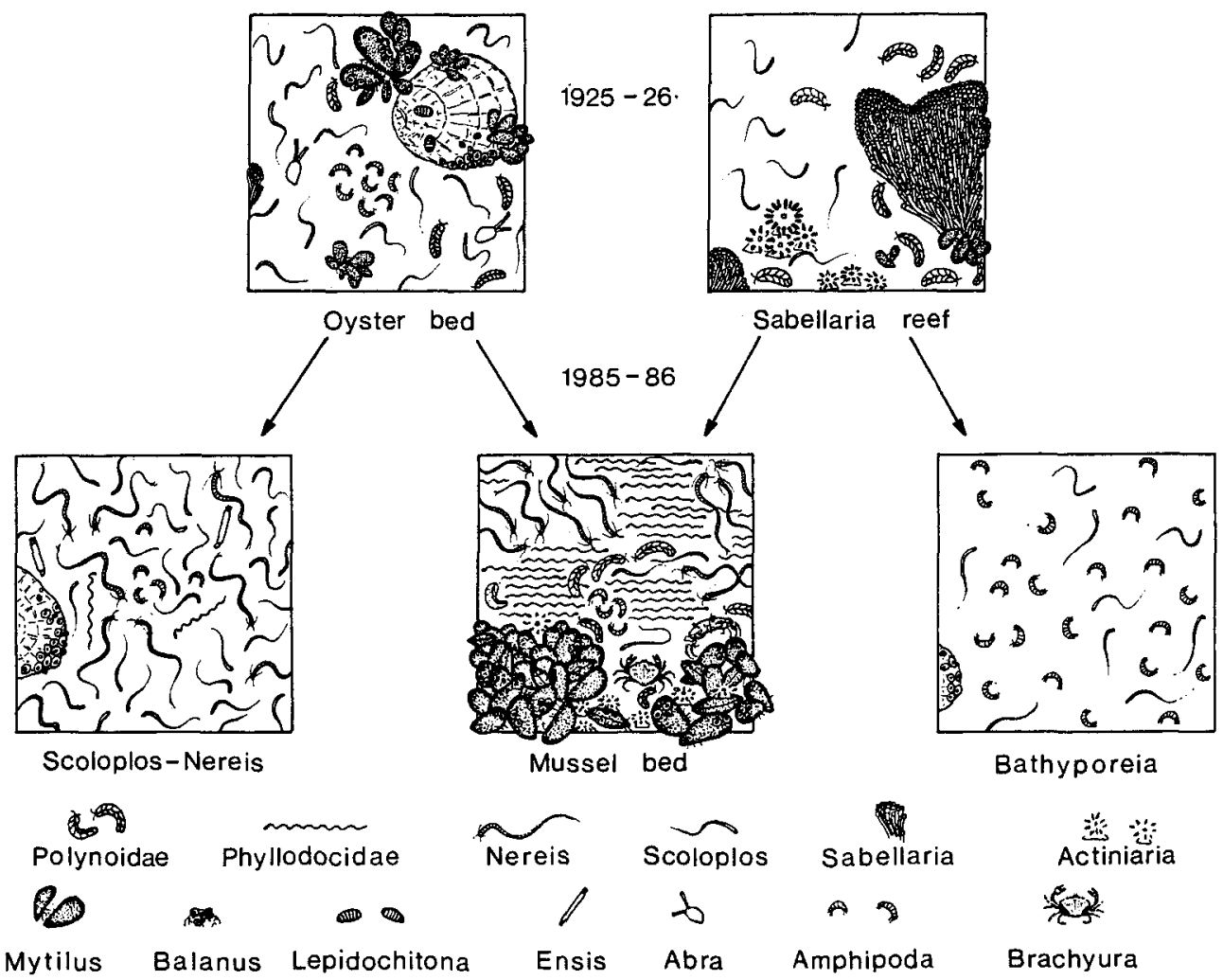

Fig. 3. Oyster beds and Sabellaria reefs of the 1920 s were substituted within 60 years by mussel beds, a polychaete assemblage, or an amphipod assemblage. Number of symbols reflects abundance

combining the long-term comparison with a short-term one to differentiate between real and spurious differences, and (3) by studying long-term changes in adjacent regions and restricting the conclusions to the consistent observations.

If any real long-term changes occurred, then the fauna sampled in distant years must show less similarity and a higher degree of species turnover than the fauna from consecutive years. This is clearly the case in the present study. At the species level, the same long-term trend must be apparent in both consecutive years, if it is to be regarded as reliable. For example in 1925-26, only 4 shore crabs were found below $2.7 \mathrm{~m}^{2}$. In 1985 , we found 100 but only 6 in 1986. Consistency is lacking and therefore evidence is insufficient for a long-term change in the abundance of Carcinus maenas.

In 1980, Riesen \& Reise (1982) revisited sampling sites of $\mathrm{H} \& \mathrm{~K}$ in the Lister Ley, island of Sylt. The Lister Ley is a tidal inlet very similar to the Norderaue, and is located about $40 \mathrm{~km}$ further north. If climate, pollution, or fishery are considered as potential agents of long-term changes in the fauna, then both areas should exhibit the same trends. Discrepancies either point to local effects, year-to-year variability or to sampling errors. 
The general trends are the same in both areas, and there is also a close correspondence on the species level. Oyster beds and Sabellaria reefs vanished, while mussel beds expanded and infaunal density increased. The total number of species remained approximately the same. In the 1920s, Sertularia cupressina, Sagartiogeton undatus, Lepidochitona cinerea, Ostrea edulis, Abra alba, Venerupis pullastra, Sabellaria spinulosa, Cheirocratus sundevalli and Psammechinus miliaris were common in both areas. In the 1980 s, these species were rare or absent, again in both areas. Vice versa, Mytilus edulis, Nereis virens, phyllodocid and other polychaetes, and Bathyporeia sarsi became consistently more numerous in the $1980 \mathrm{~s}$.

Discrepancies are few. Increased abundances of polynoid polychaetes and of the cockle Cerastoderma edule in the Lister Ley could not be confirmed in the Norderaue, and an increased abundance of Lanice conchilega in the Norderaue did not occur in the Lister Ley. Species not found in both areas constitute less reliable evidence for a longterm trend.

\section{Turnover of epifaunal species}

Species lists and relative abundances of the epifauna on the oyster beds of the North Frisian Wadden Sea are provided by Möbius (1893) for the period 1869 to 1891, by Hagmeier \& Kändler (1927) for the 1920s, and by Hagmeier (1941) for the 1930s. Apparently, there occurred no conspicuous changes throughout this time span, except for the ongoing decline of the oyster population. According to Kröyer (1837, cited in $\mathrm{H} \&$ $\mathrm{K})$, the population size of Ostrea edulis in the Wadden Sea between the Eiderstedt peninsula in the south and the Skallingen peninsula in the north, started to decrease around 1800. A very drastic decline is well documented for the late $1870 \mathrm{~s}\left(\mathrm{H} \& \mathrm{~K}_{\mathrm{i}}\right.$ Möbius, 1877; Reise, 1980).

During an official revision in 1924 and 1925, an average of 3.4 oysters per dredge haul was obtained from the beds in the Norderaue (W, S and N in Fig. 1). The annual yield from these beds for the period 1910 to 1923 was approximately 97,000 oysters. According to revisions in 1932 and 1939, the average per haul was only 1.5 oysters (Hagmeier, 1941). The last record is from 1940. Two hauls were taken on bed $W$ and one oyster was caught. Similarly, for other parts of the northern Wadden Sea there are no later records than 1940. Presumably, Ostrea edulis became extinct in the entire region in the 1940 s or 1950 s.

Möbius (1877) blames the fishery for the decline in the 1870s. H \& $\mathrm{K}$ suggest that this overexploitation diminished the number of spawners to such an extent that the population was unable to persist under the current climatic conditions. This argument implies that oysters became established in the Wadden Sea when the climate was different. Once established, the strong population was able to resist all changes until the fishery responded more to the market than to the stock size of the oysters. At the beginning of this century, attempts were made to restock the natural beds with imported oysters. For example, bed $W$ was restocked with 50000 Dutch oysters in 1925 . This and all other attempts failed (Hagmeier, 1941; Hagmeier \& Schubert, 1930; Kändler, 1928).

Large oyster shells were infested with the sponge Cliona celata Grant and the polychaete Dodecaceria concharum Oersted on all beds in the Norderaue $(\mathrm{H} \& \mathrm{~K})$. Both species are absent now. Common epigrowths were barnacles (Balanus crenatus), clumps of Sabellaria spinulosa and Halichondria panicea. In 1924, the latter exhibited massive 
growth on beds $\mathrm{S}, \mathrm{N}$ and in the northern part of W. Up to 300 clumps in a single haul were recorded (Hagmeier, 1941). In 1932, H. panicea was still superabundant in the Norderaue but became less conspicuous in 1939. We found this sponge only in the northern part of W: 4 clumps in 1985 and 2 clumps in 1986.

Sabellaria clumps were recorded from all beds in the Norderaue in 1924. The massive reefs occurred mainly below the depth range of the oyster beds ( $>5 \mathrm{~m}$ below LTL). A dredge was immediately filled with clumps of agglutinated tubes. Trawling was impossible. In the 1980s, we found no reefs and no living worms, only a few small clumps with empty tubes. With this species a major habitat is gone. The reefs have been ground with heavy gear by the shrimp fishery (Riesen \& Reise, 1982).

The tube-building polychaete Pomatoceros triqueter lived on shells of oyster bed W in 1924. In 1939 it was quite common and was also found on bed $\mathrm{S} / \mathrm{N}$ (Hagmeier, 1941). In the 1980s we found none. The colonial hydroid Sertularia argentea was found on all oyster beds in the 1920s and 1930s. In the 1980s we found none. This hydroid was used for decorative purposes and was commercially harvested in the 1950s. The sea urchin Psammechinus miliaris was quite common on the oyster beds. In 1924, 14 to 20 urchins were obtained with a single haul. In the 1930s, $P$. miliaris was particularly abundant on bed $\mathrm{S} / \mathrm{N}$ (Hagmeier, 1941). We found only 4 urchins in a single haul on bed $\mathrm{S}$ in 1986. The American prosobranch Crepidula fornicata was introduced with Dutch oysters in 1934 at Sylt and presumably in 1936 into the Norderaue (Hagmeier, 1941). We found one snail on bed W, both in 1985 and 1986.

In the $1920 \mathrm{~s}$, mussel beds were restricted to the shallows $(<2 \mathrm{~m})$ above the oyster beds. Occasionally, however, mussels settled within the oyster beds, attached to the shells, accumulated silt, and the oysters died ( $\mathrm{H} \& \mathrm{~K})$. On beds $\mathrm{W}, \mathrm{S}$ and $\mathrm{N}$, young mussels were found in 1925 and 1926. In April 1927, a grab of $0.1 \mathrm{~m}^{2}$ contained 42 mussels (Hagmeier, 1941). In 1932 these mussels were gone but a heavy spatfall was observed on the northern part of bed $\mathrm{W}$ in 1940. Bed $\mathrm{S}$ and $\mathrm{N}$ remained free of mussels.

In the 1980 s we found mussels distributed over the entire depth range of the Norderaue. They were considerably more common than in the 1920s. This was more obvious in 1985 than in 1986. At the same time, a prospering mussel fishery intensified the exploitation of the natural beds.

\section{Interpretation of faunal changes}

Six hypotheses are discussed as potential explanations for the observed long-term changes in the benthic fauna of the Norderaue. These hypotheses do not exclude each other, they are additive and may interact.

(1) Hypothesis of natural change: All differences in faunal composition between the 1920s and 1980s are caused by natural processes alone, such as climatic variation, species extending and retracting their ranges, unbalanced predator-preypathogen relations. In such a case, there will be no conspicuous changes in overall abundance and species richness, nor in the relation between functional groups or life forms. Changes are apparent only at the species level. This prediction does not hold. Conspicuous losses are confined to the epifauna, and the infauna shows an overall increase in abundance. Some events, however, may be due to natural causes. A comparison of surveys separated by decades cannot differentiate between unidirectional 
trends and population oscillations with periods of several years or more. Natural longterm cycles are expected to occur in the marine environment (Gray \& Christie, 1983; Steele, 1985), and this imposes a dose of uncertainty on any conclusions.

(2) Hypothesis of $\mathrm{changed}$ predation: Benthic abundance follows the fluctuations of predation pressure by decapod crustaceans, demersal fish and diving ducks. Shrimp, small crabs and fish, prey fairly indiscriminately on early bottom stages, causing an overall decline in the benthic community (Reise, 1985). Adult crabs, starfish and diving ducks particularly affect the bivalves. $\mathrm{H} \& \mathrm{~K}$ present the catch of 19 trawls taken from oyster beds in the 1920s. The relative abundances in catch and by-catch resemble those of the 1970s (cf. Dankers \& de Veen, 1978: Table 3). Tiews (1983) analysed the catch and by-catch of the shrimp fishery for the period 1954 to 1981 . Cod, dab, plaice and a few other fish increased in the 1970s, and shrimp also show a slightly increasing trend over the years in the Wadden Sea of Schleswig-Holstein. If at all, this suggests an increased predation pressure on the benthos, which is in conflict with the observed high infaunal abundance in the 1980s. Mussels are preyed upon by eider ducks. This latter population has not declined in recent years (Swennen, 1980), and thus provides no explanation for the spread of mussels.

(3) Hypothesis of toxification: Industrial pollutants accumulate in the benthos and cause a general impoverishment, decreased abundance and loss of species. Large and long-lived forms probably suffer more than small and rapidly breeding species. Toxic pollutants cannot be blamed for the observed changes because losses occurred only in the epifauna.

(4) Hypothesis of organic enrichment: Nutrients from agricultural runoff and human communities stimulate primary production, and more food becomes available for the benthic fauna. Abundances will increase, and species characteristic of muddy sediments will spread. Organic enrichment may eventually cause oxygen deficiencies; however, in a tidal water body with high current velocities this is only to be expected under extreme eutrophication.

Enhanced organic input and primary production provide a plausible explanation for the concurrent increase in mussels and infauna. Mussel abundance also increased in the eutrophicated Baltic Sea (Brey, 1986; Cederwall \& Elmgren, 1980; but cf. Persson, 1981). Increased polychaete abundance may be a direct response to organic enrichment (Anger, 1977; Dauer \& Conner, 1980; Dorsey, 1982) or to the spread of mussels (Kaspar et al., 1985; Mattson \& Lindén, 1983; Riesen \& Reise, 1982). Evidence for coastal eutrophication in northern Europe is accumulating (Rosenberg, 1985), and long-term changes in the benthos of the Kattegat are also in line with this interpretation (Pearson et al., 1985).

(5) Hypothesis of dredging and trawling effects: From the Norderaue, gravel and sand are extracted. Dredges were used to collect oysters and are used to harvest mussels. Shrimp trawling is very common. All these disturbances particularly affect the epifauna and some sessile and fragile infauna (Blegvad, 1951; de Groot, 1984). The loss of epifaunal species and of infaunal bivalves in the Norderaue, suggests that dredging and trawling had some effects. Sabellaria reefs were destroyed by the shrimp fishery (Riesen \& Reise, 1982).

(6) Hypothesis of attending oyster and mussel beds: In the 1930s, commercial fishery on molluscs switched from oysters to mussels in the Norderaue (Hagmeier, 1941). Oyster beds were cleared of invading mussels; massive sponges, 
starfish and crabs were removed; shells were cleaned to provide suitable space for the attachment of oyster spat $(\mathrm{H} \& \mathrm{~K})$. This attendance may have contributed to the persistence of the oyster bed community.

The mussel fishery transplants young, crowded mussels from the shallows where initial survival is high, to deeper sites where mussels spread and grow faster $\left(\mathrm{H} \& \mathrm{~K}_{\text {; }}\right.$ Korringa, 1980). This may have promoted the expansion of mussel beds over the entire depth range of the Norderaue. However, mussel fishery was rather extensive over the last decades and intensified only very recently in the northern Wadden Sea. It does not seem very probable that the general spread of mussels was possible without additional food.

Without any reference areas, where neither fishery nor any other exploitations are allowed, it will be impossible to differentiate between the last three hypotheses. None is comprehensive enough to explain alone all the observed long-term changes in the benthos of the Norderaue. We conclude that a combination of coastal eutrophication, fishery and dredging effects caused the spread of mussels, the increase of infaunal abundance, and the loss of epifaunal species.

Acknowledgements. We thank N. Kruse and P. Elvert of R.V. "Mya" for skillful assistance in sampling the benthic fauna. Dr. H. J. Aurich helped with old literature.

\section{LITERATURE CITED}

Anger, K., 1977. Benthic invertebrates as indicators of organic pollution in the western Baltic Sea. Int. Revue ges. Hydrobiol. 62, 245-254.

Blegvad, H., 1951. Fluctuations in the amounts of food animals of the bottom of the Limfjord in 1928-1950. - Rep. Dan. biol. Stn 53, 3-16.

Brey, T., 1986. Increase in macrozoobenthos above the halocline in Kiel Bay comparing the 1960s with the 1980s. - Mar. Ecol. Prog. Ser. 28, 299-302.

Cederwall, H. \& Elmgren, R., 1980. Biomass increase of benthic macrofauna demonstrates eutrophication of the Baltic Sea. - Ophelia (Suppl.) 1, 287-304.

Dankers, N. M. J. A. \& Veen, J. F. de, 1978. Variations in relative abundance in a number of fish species in the Wadden Sea and the North Sea coastal areas. In: Fishes and fisheries of the Wadden Sea. Ed. by N. Dankers, W. J. Wolff \& J. J. Zijlstra. Balkema, Rotterdam 77-105. (Rep. Wadden Sea Working Group. 5.)

Dauer, D. M. \& Conner, W. G., 1980. Effects of moderate sewage input on benthic polychaete populations. - Estuar. coast. mar. Sci. 10, 335-346.

Dorsey, J. H., 1982. Intertidal community offshore from the Werribee sewage-treatment farm: an opportunistic infaunal assemblage. - Aust. J. mar. Freshwat. Res. 33, 45-54.

Gray, J. S. \& Christie, H., 1983. Predicting long-term changes in marine benthic communities. - Mar. Ecol. Prog. Ser. 13, 87-94.

Groot, S. J. de, 1984. The impact of bottom trawling on benthic fauna of the North Sea. - Ocean Managem. 9, 177-190.

Hagmeier, A., 1941. Die intensive Nutzung des nordfriesischen Wattenmeeres durch Austern- und Muschelkultur. - Z. Fisch. 39, 105-165.

Hagmeier, A. \& Kändler, R., 1927. Neue Untersuchungen im nordfriesischen Wattenmeer und auf den fiskalischen Austernbänken. - Wiss. Meeresunters. (Helgoland) 16, 1-90.

Hagmeier, A. \& Schubert, A., 1930. Untersuchungen über die Biologie der Auster. Nr. 4. Die Austermbrut im Wattenmeer. - Wiss. Meeresunters. (Helgoland) 18, 1-26.

Kändler, R., 1928. Untersuchungen über die Biologie der Auster. Nr. 3. Verbreitung und Wachstum der Austernbrut im Wattenmeer. - Wiss. Meeresunters. (Helgoland) 17, 1-35.

Kaspar, H. F., Gillespie, P. A., Boyer, I. C. \& MacKenzie, A. L., 1985. Effects of mussel aquaculture on 
the nitrogen cycle and benthic communities in Kenepuru Sound, Marlborough Sounds, New Zealand. - Mar. Biol. 85, 127-136.

Korringa, P., 1980. Management of marine species. - Helgoländer Meeresunters. 33, 641-661.

Mattson, J. \& Lindén, O., 1983. Benthic macrofauna succession under mussels, Mytilus edulis L. (Bivalvia), cultured on hanging long-lines. - Sarsia 68, 97-102.

Möbius, K., 1877. Die Auster und die Austernwirthschaft. Wiegandt, Hempel \& Parey, Berlin, 126 pp. Möbius, K., 1893. Über die Tiere des schleswig-holsteinischen Austernbänke, ihre physikalischen und biologischen Lebensverhältnisse. - Sber. preuss. Akad. Wiss. 7, 33-58.

Nilsson, S. G. \& Nilsson, I. N., 1983. Are estimated species turnover rates on islands largely sampling errors? - Am. Nat. 121, 595-597.

Pearson, T. H., Josefson, A. B. \& Rosenberg, R., 1985. Petersen's benthic stations revisited. I. Is the Kattegat becoming eutrophic? - J. exp. mar. Biol. Ecol. 92, 157-206.

Persson, L.-E., 1981. Were macrobenthic changes induced by thinning out of flatfish stocks in the Baltic Proper? - Ophelia 20, 137-152.

Reise, K., 1980. Hundert Jahre Biozönose. - Naturw. Rdsch., Stuttg. 33, 328-335.

Reise, K., 1985. Tidal flat ecology. Springer, Berlin, $191 \mathrm{pp}$.

Riesen, W. \& Reise, K., 1982. Macrobenthos of the subtidal Wadden Sea: revisited after 55 years. Helgoländer Meeresunters. 35, 409-423.

Rosenberg, R., 1985. Eutrophication - the future marine coastal nuisance? - Mar. Pollut. Bull. 16, $227-231$.

Schoener, T. W., 1983. Rate of species turnover decreases from lower to higher organisms: a review of the data. - Oikos 41, 372-377.

Steele, J. H., 1985. A comparison of terrestrial and marine ecological systems. - Nature, Lond. 313, 355-358.

Swennen, C., 1980. Eider (Somateria mollissima L.). In: Birds of the Wadden Sea. Ed. by C. J. Smit \& W. J. Wolff. Balkema, Rotterdam, 87-84. (Rep. Wadden Sea Working Group. 6.)

Tiews, K., 1983. Über die Veränderungen im Auftreten von Fischen und Krebsen im Beifang der deutschen Garnelenfischerei während der Jahre 1954-1981. - Arch. FischWiss. 34, 1-156. 